\title{
Research on Diversified Innovative Financing Models Based on Xiaomi Corporation
}

\author{
Weijian Li, Chenggang Li ${ }^{*}$ \\ Business School, Beijing Institute of Fashion Technology, Beijing, China \\ Email: *ccid205@126.com
}

How to cite this paper: $\mathrm{Li}, \mathrm{W} . \mathrm{J} .$, \& $\mathrm{Li}, \mathrm{C}$. G. (2021). Research on Diversified Innovative Financing Models Based on Xiaomi Corporation. Theoretical Economics Letters, 11, 1210-1220. https://doi.org/10.4236/tel.2021.116077

Received: October 31, 2021

Accepted: December 21, 2021

Published: December 24, 202

Copyright $\odot 2021$ by author(s) and Scientific Research Publishing Inc. This work is licensed under the Creative Commons Attribution International License (CC BY 4.0).

http://creativecommons.org/licenses/by/4.0/

(c) (i) Open Access

\begin{abstract}
The financing methods of enterprises need to be constantly adjusted and updated in line with the progress of the times, industry development and business innovation. In recent years, Internet companies have deepened their diversified financing strategies and adopted diversified financing modes such as offshore financing and cooperative development, with a view to enhancing their financing capabilities and thus achieving the purpose of financial strategy transformation. Xiaomi, as a leading Internet company, is not only unique in its business model and management strategy but also breaks through the tradition of its financial strategy and takes the lead in proposing and practicing a series of new financing concepts and methods. This paper analyses the current situation of existing financing models, analyzes the practical significance of diversified innovative financing for enterprises based on Xiaomi's breakthroughs in financing models, and makes suggestions for enterprises to carry out enhanced financing.
\end{abstract}

\section{Keywords}

Diversified Financing, Innovative Financing Models, Xiaomi Corporation

\section{Introduction}

Since entering the $21^{\text {st }}$ century, China's Internet industry has grown strongly, with the overall revenue scale of the top 100 companies hitting a record high in 2020 and Internet business revenue reaching RMB 3.5 trillion, an overall increase of $28.2 \%$ compared to 2019 . The market's rapid growth in readiness requires strong financial support, while the Internet industry, as a high-tech industry, has a highly competitive market and high investment risks. Internet enterprises, mainly private enterprises, have difficulty competing with state-owned ${ }^{\star}$ Corresponding author. 
enterprises or other low-risk industries in terms of financing advantages. On the one hand, Internet companies are asset-light enterprises, so it is difficult to obtain financing through bond financing models; on the other hand, the development of Internet companies requires stable financial support, and the high-risk characteristics limit the footsteps of many conservative investors. Therefore, it is of great practical significance to study the innovative financing mode of Internet enterprises. Taking Xiaomi as an example, this paper studies the financing model of Internet enterprises and puts forward suggestions for the financing of Chinese Internet enterprises.

\section{Research Status of Research on Multiple Financing Models for Enterprises}

There has been a great deal of research by scholars on the diversified financing models of enterprises. In their studies, Li (2007a), Li (2007b) and Gao (2010) have analysed the current situation of financing for high-tech Internet enterprises and proposed emerging financing methods such as intellectual property guarantee financing and venture capital. Yan (2011) argued that high-tech enterprises should innovate in financing models. Wang (2012) discusses the financing models that should be used in each life cycle according to the life cycle theory, and believes that the current traditional financing models can hardly meet the development needs of such enterprises, and we need more innovation in the financing methods. From the perspective of diversification, Fu (2020) analyzes the financing mode and approach of enterprises, and thinks that enterprises should establish diversified financing channel platforms and guarantee mechanisms. Zhang (2015) pointed out that the financing mode of debt financing should be used more often in the start-up and growth stages of high-tech enterprises. Fan (2019) takes Xiaomi's signing of a betting agreement for financing as a case study, analyzes a series of processes for its betting success, and finally draws relevant practical insights. Yan (2019) and Zhang (2020) both conducted studies on the financing and listing of Xiaomi enterprises.

Some domestic scholars have proposed that enterprises should innovate in their financing methods, especially for high-tech enterprises such as the Internet. This paper takes this as an entry point to explore the diversified innovation of Internet enterprises in financing mode through the study of Xiaomi's financing mode.

\section{The Current Status of Our Financing Model}

\subsection{Types of Corporate Financing Models}

American economists Dou (2017) pointed out that the forms, ways, means and channels of transferring funds from savings to investment are collectively called financing methods, which are actually a kind of resource allocation process in the form of supply and demand of funds, and can be divided into the following types according to different criteria (Figure 1): internal financing and external 


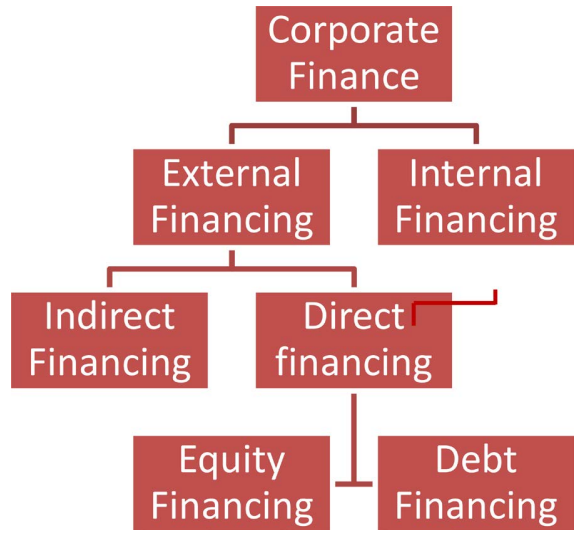

Figure 1. The relationship between the six types of corporate.

financing according to different sources; debt financing and equity financing according to different property rights of funds; indirect financing and direct financing according to whether financial intermediaries are used in the financing process. According to the different sources, it can be divided into internal financing and external financing; according to the different property rights of funds, it can be divided into debt financing and equity financing; according to whether to use financial intermediaries in the financing process, it can be divided into indirect financing and direct financing.

\subsection{Financing Model for Chinese Internet Companies}

For Internet companies, there are few Internet listed companies listed in China's Shenzhen and Shanghai markets. The characteristics of the industry make the equity and other financing methods of companies in the industry with certain similarities, but at the same time different from other industry companies. China has relatively few financing channels, strict policy requirements and limited financing scale. To summarize the current situation of financing for Chinese Internet companies, the following is the status quo.

- Internet companies prefer exogenous financing. Internet technology companies need a lot of financing to provide themselves with financial support if they want to continuously output good technology products and technology services in a highly competitive market environment. Analyzed from the aspect of financing structure, Internet companies have a low proportion of internal financing and mainly prefer external financing. Internet companies are generally "burning" and "losing" money during the start-up and growth periods, making the possibility of financing through retained earnings very slim.

- Equity financing is the main financing method for Internet companies. Most of Internet technology companies are "light asset" companies with mainly intangible assets. Compared with "heavy asset" companies, the intangible assets owned by "light asset" companies are difficult to quantify. In addition, they are generally established in a short period of time and have not yet 
formed a good credit accumulation, so it is difficult to obtain a large number of funds required for their own development through debt financing. Therefore, for Internet companies, equity financing is the main financing method, accounting for more than $50 \%$ of the total.

- Vulnerable to private equity financing models are hot. Internet is high-risk, fast-growing and competitive, but once an Internet company dominates in a niche area, there will be explosive growth in the later stage, and the revenue and development space will expand rapidly, such as the dominant position in the search engine field of Baidu. According to the statistics of Qingke Research Data Center, more than $75 \%$ of the Internet companies listed in China have raised funds through private equity financing before going public.

- Internet companies prefer the financing method of venture capital. As the product technology continues to mature and has a certain number of users, the enterprise has the possibility of industrialization and commercialization with high risk and high development potential, which will attract a lot of venture capital. For example, Jingdong's five rounds of financing from 2007 to 2013 were mainly to cover the funding gap caused by Jingdong's price war, and there was a betting agreement in its financing agreement.

\section{Analysis of the Financing Model Based on Xiaomi}

\subsection{Xiaomi Company Introduction}

Founded on March 3, 2010 by Lei Jun, Xiaomi is a global mobile Internet company focused on the development of smart hardware and electronic products, as well as an innovative technology company focused on high-end smartphones, Internet TVs and smart home ecological chain construction. Xiaomi's products can be broadly divided into three parts: smartphones, loT and lifestyle consumer products, and Internet service products. Xiaomi has built the world's largest consumer IoT IoT platform through its own production and cooperation with ecological enterprises, occupying about $1.7 \%$ of the global market share. Through cell phone terminals and the self-developed MIUI with 242 million monthly active users, it provides a wide range of Internet service products to a wide range of users. On July 9, 2018, Xiaomi was listed on the main board of the Hong Kong Stock Exchange, becoming the first company in China to be listed under the "One Share, One Vote" equity structure.

\subsection{Xiaomi's Financing History}

Xiaomi's equity financing since its inception is as follows: Xiaomi's equity financing can be divided into two phases, the first phase being the private equity financing prior to the IPO and the second phase being the preparation and formal IPO on the HKSE.

In the first phase, in April 2010, Lei Jun and his team founded Xiaomi, and in September 2010, Xiaomi started its first round of preferred stock financing (Table 1 ), the main purpose of this round of financing was product development. 
Table 1. Xiaomi's financing history.

\begin{tabular}{|c|c|c|c|c|}
\hline Rounds & Time & $\begin{array}{l}\text { Financing amount } \\
\text { (million dollars) }\end{array}$ & $\begin{array}{l}\text { Enterprise Valuation } \\
\text { (billion dollars) }\end{array}$ & Major Investors \\
\hline Round A & $2010 / 9 / 28$ & 1025 & - & Founding Team, Chenxing Capital, Qiming Venture Capital \\
\hline Round B & $2010 / 12 / 21$ & 2750 & 2.5 & Chenxing Capital, Qiming Venture Capital, IDG Capital \\
\hline Round B+ & $2011 / 4 / 11$ & 275 & - & Wealth plus investment limited, Bin Lin \\
\hline Round $\mathrm{B}++$ & $2011 / 8 / 24$ & 60 & - & Guangping Zhou, Bin Lin \\
\hline Round C & $2011 / 9 / 30$ & 8800 & - & $\begin{array}{l}\text { Chenxing Capital, Shunwei Capital, IDG Capital, } \\
\text { Qiming Venture Capital, etc. }\end{array}$ \\
\hline Round C+ & $2011 / 11 / 10$ & 210 & 10 & Gaotong, Apoletto, prevailing limited \\
\hline Round D & $2012 / 6 / 22$ & 216 & 40 & Apoletto, Temaek, etc. \\
\hline Round E & $2013 / 8 / 5$ & 1000 & 100 & GIC, DST, All-stars, Houpu Capital, Yunfeng Capital, etc. \\
\hline Round F & $2014 / 12 / 23$ & 11340 & 450 & DST, GIC, Houpu Capital, etc. \\
\hline
\end{tabular}

(Data source: Xiaomi Group public offering CDR prospectus).

At the end of June 2012, Xiaomi completed its Series D financing, a round of financing that still stands on the basis of the company's core business and the deepening of its main products. At the end of 2014, Xiaomi announced the completion of its fifth round of financing, a round of financing plan that, on the one hand, guarantees In late 2014, Xiaomi announced the completion of its fifth round of financing, which, on the one hand, secured Xiaomi's investment and acquisition efforts for its system ecosystem companies in China, and, on the other hand, the introduction of international investment institutions also provided the necessary support for Xiaomi's strategic expansion plans overseas, which led to Xiaomi's successful entry into the Indian market and its globalization strategy since then. With the expansion of Xiaomi's scale and increasing business segments, the scale of demand for capital has also increased significantly, with Xiaomi securing over $\$ 1.1$ billion in Series E financing. In late 2017, Xiaomi began preparations for its initial public offering on the Hong Kong Stock Exchange, and Xiaomi's equity financing entered its second phase.

In the second phase, Xiaomi faced and core issues in the HKSE listing for its own industry affiliation and business model definition. On July 9, 2018, Xiaomi Group was officially listed in Hong Kong with an issue price of HK \$17 and a valuation of US\$54.3 billion. As the first Hong Kong-listed company with different shareholdings, Xiaomi realizes the separation of ownership and control through A/B shares. With the increase of Xiaomi's financing channels, the scale of Xiaomi's financing has also increased very significantly. Xiaomi used private equity financing at the beginning of the company's development, also Xiaomi issued preferred shares. And the scale of financing is also showing a rising trend, indicating that the development of Xiaomi also shows a good development trend, which only leads to the continuous increase of investors' investment in 


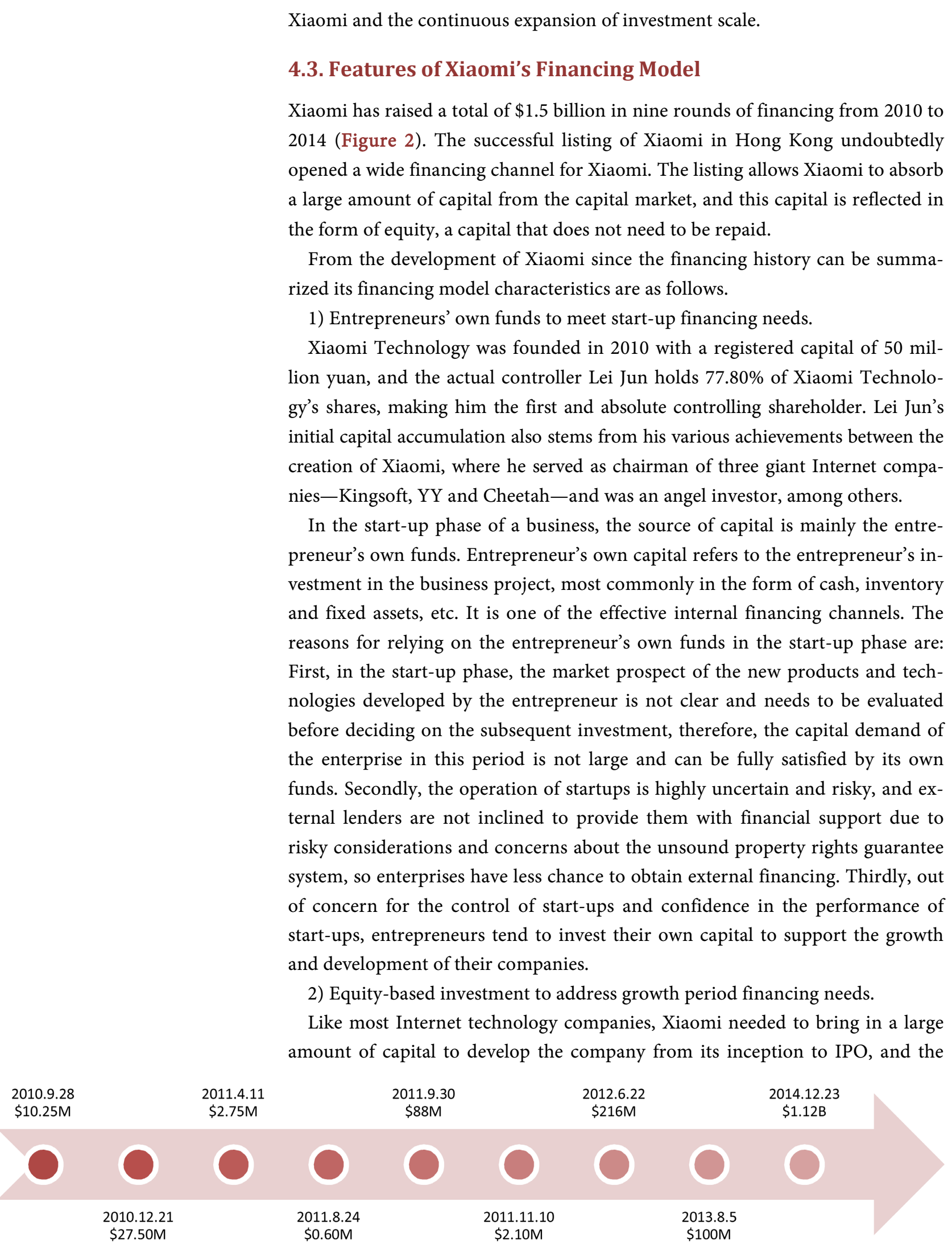

Figure 2. Xiaomi financing time node chart. 
financing method adopted was mainly equity financing, but after several rounds of equity financing, it did not affect Lei Jun and his founding team's authority over Xiaomi's business decisions, as the company adopted not a common stock financing method but a convertible and redeemable preferred stock financing Instead of using common stock financing, the company used a convertible and redeemable preferred stock financing to meet its capital needs. This financing method has the characteristics of both debt financing and equity financing. Preferred stockholders can receive fixed interest payments from the company, but they do not have the right to vote on the company's operations, i.e., they do not have the right to ask questions about the company's management activities, so they are generally less attractive to investors.

Xiaomi's equity financing can be divided into two stages: the first stage is the private equity financing before the IPO, and the second stage is the preparation and formal IPO on the Hong Kong Stock Exchange. If investors choose to exercise their options, they can convert their preferred shares into a certain number of common shares at the agreed conversion price; if they do not, the company will redeem the preferred shares in the hands of investors at the agreed interest rate and pay interest, which not only improves Xiaomi's attractiveness to investors, but also protects founder Lei Jun's control and voice over Xiaomi so that the company can develop in accordance with the long-term development strategy set by the founder and his management team. The uniqueness of Xiaomi's financing strategy lies not only in the fact that its choice of financing method fits well with its actual situation, but more importantly, its financing strategy well compensates for the higher financing cost and the easy loss of control brought by equity financing.

3) Combination of endogenous financing and exogenous financing.

Financing has always been one of the problems of private enterprises. Xiaomi's capital model brings a variety of channels of financing for the enterprise, mainly divided into endogenous financing and exogenous financing. Xiaomi's endogenous financing includes not only the profits obtained by the company through its own profit mechanism, but also the financing method by making employees partners. Xiaomi's exogenous financing includes not only equity financing, but also debt financing.

Xiaomi's debt financing is mainly through the issuance of US dollar bonds, Panda bonds and convertible bonds. The issuance of U.S. dollar-denominated bonds is a highly recognized and publicly tradable bond, and the company's issuance of U.S. dollar-denominated bonds is conducive to the development of multi-level and diversified financing channels, enhancing the efficiency of the company's financial operations and the flexibility of its financial management.

4) Gradually expand commercial credit financing.

Commercial credit financing refers to the borrowing and lending business between enterprises through commodities when carrying out product trading activities, and this kind of debt relationship is very common in the process of 
market economic development. Its specific manifestations include: accounts payable, etc. It has the advantages of low financing cost and less restrictive conditions, but the funds raised are generally small and the term is short, so if it exceeds the discount period it will bear greater costs and credibility loss.

Xiaomi adopts the model of supplying and OEM products from ecological chain enterprises, which has strong control over sales channels and brand influence from the sales environment, and this control is especially strong for the participating enterprises in the Xiaomi ecological chain system. According to Xiaomi's financial report, the company's average billing period for suppliers is 38 days. As Xiaomi's market position in the new retail sector solidifies and the scale effect of the product supply companies joining its eco-chain system gradually emerges, the larger the scale of funds it can occupy in inventory and accounts receivable will be. Xiaomi's enhanced commercial credit and increased voice guarantees the feasibility of using this method to supplement financing of a certain scale, and also reduces the overall financing cost through commercial credit financing.

Xiaomi has taken full advantage of this advantage by adopting the "upstream finance-like model" for financing, i.e. taking up suppliers' funds through deferred payment and obtaining short-term interest-free loans. In the three consecutive years since 2015, commercial credit financing accounted for more than $65 \%$ of Xiaomi's total debt financing (Figure 3), which shows that commercial credit financing is one of the most important sources of financing for Xiaomi. This feature of Xiaomi's financial strategy also confirms the essence that Xiaomi is more of a technology consumer goods company than a pure Internet company in terms of industry segmentation.

\subsection{Insights from Xiaomi's Diversified Innovative Financing}

Xiaomi is currently the fastest growing Internet-based company in China, and

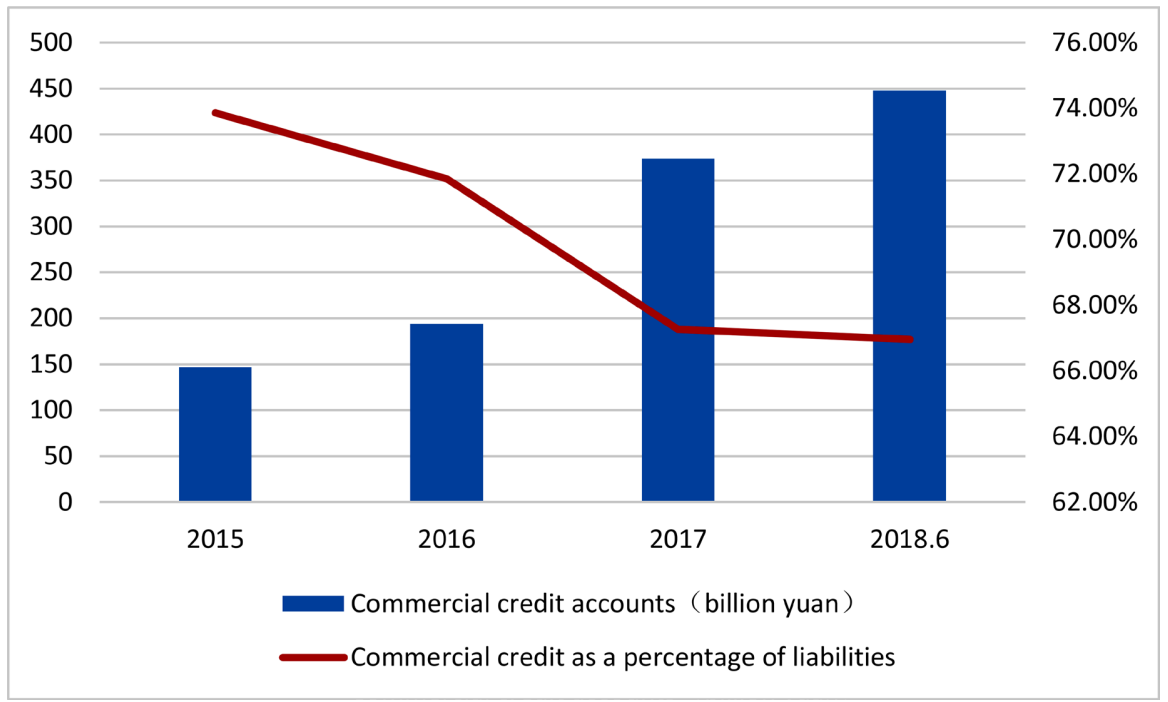

Figure 3. Xiaomi's commercial credit possessions. 
has rapidly grown and transformed into a technology-based consumer goods company with the windfall of the mobile Internet industry, creating many industry firsts. Based on its unique business model and operating philosophy, Xiaomi's overall and financial strategies are unique in China and have much to learn from similar companies, especially the large number of Internet and technology-based companies that have grown rapidly in recent years.

Xiaomi's financing strategy not only serves the needs of its overall strategy, but also relies on the development of its business to continuously create new channels. Xiaomi's financing strategy is mainly developed in line with the company's overall strategy and business development requirements, and is generally characterized by the explosive power of equity and commercial credit financing as the driving force, with various ways and plans to control financing costs and risks. The rapid development of Xiaomi's business is directly reflected in the scale, direction and period of investment, which in turn also places higher demands on the scale and stability of the company's financing strategy. In line with each step of Xiaomi's strategic adjustment, Xiaomi's financing strategy has also been continuously adjusted, from early equity financing to IPO financing, which solved the shortage of funds for large-scale investment; and then used the characteristics of its aggravated voice in the constructed industrial chain to carry out large-scale commercial credit financing to ensure the quality and efficiency of operation management.

The way companies finance themselves needs to be adjusted and pushed forward with the progress of the times, industry development and business innovation. The innovation of financial strategy is reflected in every way of financing, etc. and profit distribution, and each way needs to be tapped in the development of business. Diversified and innovative financing concepts and methods can continuously inject new vitality into the development of enterprises, maintaining their growth while reducing their business risks.

Xiaomi is unique not only in its business model and management strategy, but also in its financial strategy, which breaks through the tradition and takes the lead in proposing and practicing a series of new financing concepts and methods. Xiaomi's financing strategy takes key business development as the fulcrum to reduce financing costs by leveraging corporate valuation to reach realizations under the premise of ensuring capital needs. The investment strategy is closely coordinated with the overall business strategy, highlighting the characteristics of customer traffic as the core carrier and the investment direction built around the pooling and utilization of customer traffic.

\section{Suggestions for Countermeasures to Enhance Financing for Internet Companies}

\subsection{Choose Financing Mode According to the Stage of Development}

Internet enterprises should first pay attention to their own development stage in choosing a financing model that suits them. In the start-up period, Internet en- 
terprises are more suitable to adopt crowdfunding financing mode, which is mainly for the seed financing of start-ups. In the growth period, Internet enterprises are taking shape and have greater growth potential, so it is more suitable to adopt private equity financing mode for financing. When the development of Internet enterprises to the mature stage, Internet enterprises can be listed to carry out large-scale financing, after all, listed financing is more efficient.

\subsection{Choose Financing Model According to the Scale of Financing}

The scale of crowdfunding financing is usually small, usually ranging from hundreds of thousands to millions, which is easy to operate and can be financed quickly, but the investors involved in equity crowdfunding are more grassroots people, who are unwilling and afraid to invest a large amount of money in a risky project, so the financing of crowdfunding financing mode is usually short. Based on the above characteristics, it is difficult for the crowdfunding financing model to support the demand for large-scale and stable financing funds during the growth period of the Internet. If China's Internet enterprises urgently need short-term small-scale financing, the Internet can choose crowdfunding financing mode; preferred stock financing mode has a short development time in the territory, and there are more restrictions on issuance, so the preferred stock financing mode is not yet able to carry out large-scale financing; private equity fund financing mode generally has a larger financing scale and longer term, which can support the long-term large-scale Internet enterprise The private equity fund financing model is generally larger in size and longer in term, which can support the long-term large-scale capital needs of Internet enterprises. Internet enterprises usually need larger financing scale and frequent financing in the growth stage, so China's Internet enterprises should choose the appropriate financing mode according to their own financing needs.

\subsection{Good at Using a Combination of Different Financing Models}

When choosing a financing model, China's Internet companies cannot be limited to using only the same financing model at the same development stage, but should use a variety of financing models in conjunction with each other in order to make the financing of Internet companies more effective. China's Internet enterprises should be good at using different combinations of financing models, and can use preferred stock financing model at the same time when using other financing models, and Internet enterprises can use the way of issuing preferred stock when introducing private equity funds, so as to prevent the control of Internet enterprises from being diluted. In practice, China's Internet enterprises financing is more various financing models cross-use each other, so China's Internet enterprises should be good at using a combination of different financing models.

\section{Concluding Remark}

For the survival experience management of Internet enterprises, many enter- 
prises are due to the problem of capital and difficult to maintain long-term vitality in the fierce market environment. Through the perspective of diversification of the financing channels of enterprises to expand appropriately can greatly enhance the ability of enterprises to obtain financing, diversified financing model is conducive to improving the enterprise value of Internet enterprises. According to the situation of enterprises, the use and combination of different financing models can further promote the development of enterprises.

\section{Conflicts of Interest}

The authors declare no conflicts of interest regarding the publication of this paper.

\section{References}

Dou, M. M. (2017). Research on the Financing Methods of Internet Companies in China. University of Foreign Economics and Trade.

Fan, X. X. (2019). Exploration of Private Equity Financing under the Betting Agreement Approach-Xiaomi as an Example. Modern Commerce Industry, 40, 127-129.

Fu, L. H. (2020). A Study of Corporate Financing Strategies Based on a Diversified Perspective. Modern Business, No. 27, 156-157.

Gao, W. G. (2010). Thinking about the Construction of High-Tech Enterprise Financing System. Journal of Economic Research, No. 25, 64-66.

Li, H. M. (2007a). Research on the Financing Difficulties of Small and Medium-Sized High-Tech Enterprises with Excess Liquidity. China High-Tech Enterprise, No. 11, $28+34$.

Li, L. (2007b). Finding the Key to Corporate Finance. Enterprise Technology and Development, No. 15, 27-28.

Wang, Q. (2012). Research on the Financing of High-Tech Enterprises in China. Shanxi University of Finance and Economics.

Yan, R. T. (2011). Review and Prospect of Financing Methods for High-Tech Enterprises in China. Economic Perspectives (Mid), No. 4, 172+174.

Yan, S. L. (2019). Case Study of Financial Strategy of Xiaomi Corporation. Master's Thesis, China Academy of Fiscal Science.

Zhang, S. (2015). Research on Financing Strategy of High-Tech Enterprises in China. China Ocean University.

Zhang, S. T. (2020). Case Analysis of Xiaomi Group's Listing in Hong Kong. Master's Thesis, Northwest University for Nationalities. 